\title{
Should humanitarian interveners promote democracy after genocide?
}

\author{
STEFANO RECCHIA \\ Department of Politics and International Studies, University of Cambridge, UK
}

E-mail: sr638@cam.ac.uk

\begin{abstract}
Scholars and policymakers in the West commonly hold that liberal countries that intervene to stop genocide subsequently ought to establish democratic political institutions to enable peaceful collective self-determination. I argue that this guidance is problematic. First, introducing electoral democracy in deeply ethnically divided societies - especially but not only after genocide - often results in either tyrannical majority rule or deadlocked decision making rather than inclusive self-determination. Second, normatively speaking, John Rawls made a strong case that inclusive self-determination can be achieved through 'decent,' less than democratic political structures that enable group-based representation. Bringing these insights together, I argue that particularly for postgenocidal societies that lack prior experience with liberal democratic rule, outside interveners should stop short of actively promoting full electoral democracy and instead consider promoting hybrid political institutions that combine popularly elected bodies with customary authority structures. Such hybrid institutions can prevent tyrannical majority rule as well as decision-making deadlock. They are also likely to fit better with local culture. Therefore, they may offer a more robust foundation for peaceful self-determination. A discussion of hybrid institutions in postwar Somaliland and Bougainville illustrates how these arrangements can facilitate peaceful self-determination in practice.
\end{abstract}

Keywords: Jus post bellum; responsibility to protect; collective self-determination; power sharing; Law of Peoples; hybrid governance

It is a widely held belief that international interveners should promote democracy after ending mass atrocities because democracy advances human rights, fosters accountable government, and facilitates sustained economic growth. This 'liberal peace' paradigm has guided the activities of Western militaries, donors, and civil society organizations since the early 1990s (Western 2012). Scholarship on jus post bellum, or justice after war, has incorporated core elements of this paradigm: prominent scholars posit a 'duty' to promote postbellum democracy, especially after humanitarian interventions to stop genocide. In situations in which the incumbent regime 
has carried out or abetted genocide, the argument goes, liberal interveners ought to forcibly dismantle the existing regime and help establish democratic political institutions. This is required to punish those complicit in the crime of genocide and to enable a new political beginning based on peaceful collective self-determination (see esp. Orend 2002; Bass 2004; but also Stahn 2006; Jacob 2014; Doyle 2015; Pattison 2015). ${ }^{1}$

I argue that an unqualified injunction to promote democracy after humanitarian interventions to stop genocide is problematic. Outsiders may need to remove from power senior political elites complicit in the genocide so that vulnerable groups can be safe from further atrocities and the society can peacefully determine its own future. However, I dispute that this political transformation should necessarily culminate in the introduction of full electoral democracy.

In societies torn apart by genocide and other forms of acute communal violence, electoral democracy is unlikely to foster inclusive collective self-determination and provide adequate safeguards for ethnic minorities. Indeed, there is a significant chance that democracy will facilitate tyrannical rule by ethnic majorities (Mann 2005) or, if no single group prevails, result in deadlocked decision making (Rothchild and Roeder 2005; Horowitz 2014). Either way, the introduction of competitive elections in such deeply fractured societies can be expected to sustain high levels of communal conflict, with potentially destabilizing consequences (Snyder 2002; Sisk 2008).

Moreover, from a normative perspective, John Rawls (1999) made a strong case that inclusive collective self-determination can be achieved through 'decent,' less than democratic political structures that enable groupbased representation. Rawls's prototypical 'decent hierarchical society' is endowed with effective laws that are grounded in local custom, and although there is no democratic accountability, public consultation and deliberation ensure that policymakers accommodate the interests of all established social groups. Rawls's republican liberalism, which emphasizes the moral significance of collective self-determination, demands that we accept such nondemocratic societies as legitimate (Macedo 2004; Wenar 2006).

Bringing these insights together, I argue that, especially when a postgenocidal society lacks prior experience with liberal democratic rule, international interveners should stop short of promoting full democracy based on competitive elections. Instead, those who intervene to stop genocide - but also external peacebuilders in divided societies generally should take seriously the possibility of limiting democracy by promoting

${ }^{1}$ This responsibility to democratize is assigned specifically to liberal interveners, on the grounds that 'if it is an illiberal state that carries out the humanitarian intervention, one would not like to see it also undertake a political reconstruction [i.e., transformation] afterward' (Bass 2004, 401). 
hybrid political institutions that combine popularly elected bodies with customary authority structures. Hybrid institutions that incorporate customary authorities (e.g. traditional chiefs, members of the local nobility, and other unelected leaders) reduce the likelihood that extreme ethnonationalists will come to control the political process; furthermore, they can provide meaningful checks on executive power while facilitating pragmatic compromise and deliberation between groups. Consequently, such institutions can help prevent tyrannical majority rule as well as ethnic deadlock (Menkhaus 2000; Belloni 2012). Hybrid institutions grounded in indigenous custom are also likely to enjoy significant local legitimacy, thus encouraging political participation and voluntary compliance with public laws (Boege, Brown, and Clements 2009).

For illustration purposes, I briefly discuss existing hybrid governance structures in Somaliland and Bougainville. In Somaliland, a de facto state in the Horn of Africa that experienced significant communal violence during the 1990s, a newly established hybrid institutional structure balances the powers of a democratically elected president and lower legislative chamber with those of a nonelected upper chamber made up of clan elders. In Bougainville, an autonomous island in the South Pacific that was also torn apart by communal violence in the 1990s, outsiders have supported a postwar institutional architecture that combines a democratically elected central government with customary rule at the local level. These examples, though imperfect, indicate that hybrid institutions can foster a fairly inclusive and socially legitimate postwar politics, thus approximating the Rawlsian ideal of decency.

The article is structured as follows. Part one clarifies the meaning of collective self-determination in societies made up of several established ethnic groups. ${ }^{2}$ Part two reviews prominent arguments in favor of external democratization after humanitarian interventions to stop genocide. Part three highlights the downsides of such postbellum democracy promotion in deeply divided societies, drawing on evidence from recent cases. Part four examines in greater detail the Rawlsian argument on how decent political institutions can suffice for meaningful collective self-determination. Part five presents the case for promoting hybrid institutions that approximate Rawlsian decency in postgenocidal societies and, more generally, in societies torn apart by acute ethnic violence. Part six examines key aspects of hybrid governance frameworks in Somaliland and Bougainville to illustrate how such arrangements can facilitate inclusive self-determination in practice.

2 Throughout the article, I follow Chandra $(2005,236)$ in using the term 'ethnic' as shorthand for ethnolinguistic, tribal, and religious. 


\section{Inclusive self-determination in divided societies}

Republican liberals since Giuseppe Mazzini and John Stuart Mill have viewed the nation primarily as a political project based on the voluntary association of individuals. For these thinkers, national or collective selfdetermination encapsulates the ideal of a people that manage their own affairs through participatory political institutions and free from external domination (French and Gutman 1974; Philpott 1995). Collective selfdetermination, thus understood, does not require independent statehood, as it can be achieved through substate autonomy arrangements whereby a group exercises 'some independent political control over some significant aspect of its common life' (Buchanan 2003, 33; see also Patten 2016).

In states that are made up of several established ethnic groups, collective self-determination can occur at different levels. First, the state's domestic political structure may grant each ethnic group a right to internal selfdetermination, in the form of cultural autonomy, as well as territorial selfrule where feasible. Second, the state's ethnic groups may engage in joint collective self-determination of their common affairs. Following this second understanding, one might think, for instance, of the 'combined populations of Bosnia as constituting a unit to which the ideal of self-determination applies' (McMahan 1996, 16). This latter type of collective self-determination is quintessentially political, based on power sharing through common institutions that, ideally, will facilitate peaceful compromise end ensure that all groups have a stake in the political process.

Joint collective self-determination in ethnically diverse societies, however, is often fragile. It may break down entirely when crude nationalism motivates two or more distinct communities to resort to war in a struggle for control of the state (McMahan 1996, 19-20). Certainly no joint political community exists when one group turns savagely on another in an outbreak of genocidal violence (Walzer 1977, 101). In such circumstances, international support for ethnonational partition, or secession, may seem appealing in the abstract; however, it is usually imprudent because it may embolden restive minorities elsewhere and result in 'reverse victimization,' whereby former victims become the oppressors in their newly independent state. ${ }^{3}$ Liberal countries that intervene to stop genocide are therefore left with the difficult task of bringing the political community back together, so that peaceful coexistence and joint self-determination among the country's established groups become possible once again.

3 See Kumar (1997). Buchanan (2003, Ch. 8) nevertheless theorizes a carefully circumscribed 'remedial right to secede' for national minorities that have experienced mass atrocities. 
The domestic political process in societies torn apart by acute ethnic violence can be expected to provide majority groups with few incentives to commit to power sharing with and constitutional guarantees for ethnic minorities. In such contexts, typically 'majorities want majority rule; [meanwhile,] minorities want guarantees against majority rule' (Horowitz $2014,8){ }^{4}$ Therefore, although local ownership and self-determination must be the end, during the postwar transition, a heavy international footprint is often justified. Outside interveners may need to go beyond simply stopping the violence, and continue to act paternalistically for some time thereafter by pushing and prodding domestic political actors, in order to ensure that minority interests are taken into account - beginning at the constitutionmaking stage (Recchia 2009). Outsiders may even legitimately exercise 'quasi-sovereign powers on a temporary basis' when no functioning government exists to provide basic public goods and foster inclusive powersharing institutions (Chesterman 2004, 244; see also Paris 2004, 206).

Research suggests that in divided societies that are recovering from acute ethnic violence, inclusive power sharing offers the best chance of making peace self-sustaining (Hartzell and Hoddie 2003; Joshi and Mason 2011). It remains an open question, however, whether minority protection and joint collective self-determination in such contexts also require - or are always best achieved by - Western-style electoral democracy, and thus whether international peacebuilding should as a matter of course also entail democracy building.

\section{Political transformation after military intervention}

Most theorists deny that ending tyranny and promoting democracy are by themselves a just cause for military intervention. Even when states do have a cause for intervention that is widely considered just (e.g. self-defense or collective security), the argument goes, in most circumstances, victorious interveners do not have a right to engage in deep political reconstruction and ought to 'respect to the greatest extent possible the sovereignty of the defeated nation' (Bass 2004, 392; see also Orend 2006, 169; Doyle 2015, 169-70). ${ }^{5}$ Thus, in the aftermath of wars of counterterrorism or counterproliferation, external interveners ought to hold back from sweeping constitutional transformation. Local elites should for the most part be left to manage their country's affairs, and outsiders should interfere only as far as

\footnotetext{
${ }^{4}$ For this reason, the 'autonomous recovery' model based on endogenous stabilization by local parties (Weinstein 2005) is frequently unworkable and/or incompatible with basic safeguards for minority groups.

${ }^{5}$ See, however, Téson (2005) for a justification of interventions to end tyranny.
} 
necessary to prevent the country from again becoming a terrorist safe haven or proliferator of weapons of mass destruction (Bass 2004, 394).

At the same time, many contemporary liberals believe that genocide is different. Regimes that have carried out or abetted this particular crime, we are told, 'have no international standing' (Bass 2004, 399). The underlying assumption is that genocide - the intentional destruction, in whole or in part, of a national, ethnic, or religious group - is the summum malum, the supreme evil. It follows that not only is humanitarian military intervention justified and probably required to end the killing; but after the killing stops, the genocidal regime's continued existence cannot be tolerated because, apart from threatening the peace, it would be an affront to the most deeply held values of the liberal community of nations. ${ }^{6}$

\section{A duty to democratize genocidal states?}

Among those who are willing to endorse a vigorous dose of international paternalism in the service of postwar democracy promotion is Brian Orend, 'arguably the most influential writer on jus post bellum' (Melandri 2011, 243). Orend (2006, 95-96) believes that humanitarian military intervention 'is morally obligatory' in the presence of large-scale government brutality. Once the atrocities stop, justice requires punishment of the perpetrators. This is achieved through war crimes trials, the imposition of reparations, and 'political rehabilitation' - by which he means constitutional transformation (Orend 2006, 169). Such transformation should be 'proportional to the degree of depravity inherent in the [domestic] political structure itself' (Orend 2002, 51). When a regime has carried out truly 'atrocious' actions, such as genocide, postbellum justice requires that the 'regime be forcibly dismantled' $(2002,50)$, with the goal of 'deep structural transformation toward a peaceable liberal democratic society' (56). This 'imposition of institutional therapy' is primarily a matter of punishment; but it is also required to prevent future aggression and to enable peaceful collective self-determination (52).

Gary Bass similarly argues that humanitarian interveners have a 'jus post bellum duty to reconstruct... genocidal states' (2004, 400). Such political reconstruction, he clarifies, amounts to constitutional transformation, or 'remaking a regime' (398). It is 'the final piece of business of a humanitarian intervention to stop genocide' (398-99). For Bass, too, political reconstruction is first and foremost a matter of punishment, although it must also

${ }^{6}$ In Walzer's words, when a political regime is 'actively hostile to the very existence of entire peoples... [its] criminality... threatens those deep values that political independence and territorial integrity merely stand for in the international order' $(1977,113-14)$. 
enable peaceful self-determination and thus 'be pedagogical or reformist, not simply retributive' (396). Bass does not make his belief in a duty to democratize explicit (he merely affirms that 'broad political reconstruction' is mandated [412]). Nevertheless, this belief emerges clearly from his overall argument: after discussing the reasons that mandate broad reconstruction for genocidal states, Bass notes that 'there may also be a case for a more limited kind of foreign reconstruction' when the defeat of a dictatorial regime that was not outright genocidal leaves the country on the verge of anarchy (403). In such cases, he argues, 'the society need not be built up into a stable liberal democracy... The standard would probably be the Rawlsian category of well-ordered [i.e., decent] peoples' (403). It follows that the broader reconstruction that Bass has in mind for genocidal states requires something beyond Rawls's category of decent peoples - which can only mean liberal democracy.

What constitutes a 'genocidal state,' however, is far from self-evident. The paradigmatic case, central to Walzer's (1977, 111-16) discussion in Just and Unjust Wars, is Nazi Germany. Adopting a broader definition, Bass (2004, 399-402, at 399) suggests that even 'relatively localized butchers without global transformational objectives' who commit or support acts of genocide during civil wars - such as Slobodan Milosevic of Serbia - should count as the leaders of genocidal states and ought to be dealt with accordingly. But the focus is still on oppressive governments. Hence Bass excludes, without good reason, weak and fragile states such as Uganda and Burundi, where political violence carried out by nonstate actors operating without regime support 'often becomes sufficiently extreme and group-targeted that it qualifies as genocide' (de Waal, Meierhenrich, and Conley-Zilkic 2012, 28). Nonstate militias such as those representing the Bosnian Serbs during the 1990s or contemporary radical Salafi Islamist movements are often no less dangerous to other communities than the armies of oppressive governments. Therefore, instances of governmentsponsored genocide and genocide carried out by nonstate actors ought to be treated in the same way. ${ }^{7}$

\section{Beyond punishment}

Moralized arguments about genocidal states are 'relentlessly backwardlooking,' as Lazar $(2014,218)$ puts it; they are too focused on punishing and remedying the wrongs done by abusive strongmen, often at the risk of

\footnotetext{
${ }^{7}$ One may also question whether singling out genocide is in fact warranted: according to a United Nations report on Darfur, there is no hierarchy of international crimes, with genocide, war crimes, and crimes against humanity all constituting 'serious violations of international humanitarian law' that deserve the same degree of opprobrium and condemnation (United Nations 2005, 129).
} 
inflicting further deprivations on vulnerable civilian populations (see also Fixdal 2012, 3-22). The most important goal of postwar justice should be to relieve human suffering and build durable peace - especially after civil wars. Consequently, arguments about postbellum constitutional transformation should be primarily forward looking, meaning that punishment and compensation, while important, ought to be of secondary significance.

Recently, some scholars have defended postbellum democracy promotion based on more forward-looking, consequentialist arguments: promoting democracy is no longer portrayed as a duty linked to punishment but simply as a highly desirable means to achieve peaceful collective self-determination. Walzer, for instance, dismisses maximalist postbellum objectives in the case of humanitarian intervention' $(2012,38)$, arguing that 'the United States is not obligated to create a Swedish-style social democracy... for the simple reason that we can't do that' (42; emphasis added). Nevertheless, he is drawn toward the conclusion that interveners should 'aim at a democratically elected government' because modern democracy enables self-determination and 'offers greater protection [of ethnic minority rights and other human rights] than a regime of oligarchs, patriarchal chiefs, or clerics' (44). Doyle (2015, 148-49, 166-70) similarly supports postbellum 'transformational peacebuilding' aimed at establishing electoral democracy - not in all circumstances, but clearly when domestic groups in divided societies appear unable to negotiate a peace agreement by themselves, and a fortiori to facilitate peaceful self-determination and respect for minority rights after genocide (for similar arguments, see also Stahn 2006; Jacob 2014; Pattison 2015).

\section{Democracy and minority rights in deeply divided societies}

But does democracy actually help protect minority rights in deeply divided societies recovering from genocide and other forms of acute ethnic violence? Modern electoral democracy, broadly speaking, can take two forms: majoritarian, in which the party or coalition that wins a majority (and sometimes a mere plurality) of the vote in a popular election holds political power, or consociational, in which power sharing among a society's established ethnic groups is achieved through reserved seats for minorities in the cabinet, the parliament, and the civil service (Lijphart 1999, 2-8).

Research shows that fully consolidated liberal democracies based on the rule of law - regardless whether majoritarian or consociational - are more likely than other regime types to constrain would-be oppressors and facilitate peaceful domestic conflict resolution; however, 'authorities do not perceive any constraints on repression... until the highest levels of democracy have been achieved' (Davenport and Armstrong 2004, 551). Meanwhile, processes of democratization systematically increase state 
repression (Davenport 2007). Many transitions to democracy remain incomplete, especially in ethnically divided societies, as these societies adopt competitive elections but, absent a liberal political culture and sustainable elite bargains in favor of open government, stop far short of the liberal democracy threshold (Ottaway 2007; Hinnebusch 2014).

When majoritarian democracy is introduced in fragile, deeply divided societies, tyrannical rule by ethnic majorities may become a quasipermanent feature of the political landscape. As Michael Mann argues in The Dark Side of Democracy $(2005,2)$, 'democracy has always carried with it the possibility that the majority might tyrannize minorities, and this possibility carries more ominous consequences in certain types of multiethnic environments' - especially when 'political institutions are weak and affected by war' (7).

Under Westminster-style majoritarian democracy, plurality voting systems such as first past the post ensure that the largest group simply needs to obtain more votes than any of its competitors to control all levers of political power. Lijphart $(1999,7)$ notes that such 'pure' majoritarian democracies are relatively rare. But even electoral systems based on proportional representation can result in majoritarian democracy, especially in ethnically divided societies in which one group makes up more than half of the electorate. Majoritarian democracy typically produces executive dominance, which in postwar societies may leave strong presidents or prime ministers with few incentives to refrain from repressing minorities.

Consociational democracy, also known as power-sharing democracy, is by definition more inclusive. In its pure form, consociational democracy involves the participation of all ethnic groups in a 'grand coalition' government. Furthermore, there are reserved seats for minorities in parliament and the civil service; minority groups are granted ample autonomy, often through territorial self-rule; and each group holds a right to veto central government decisions that it perceives as harmful to its 'vital interests' (Lijphart 1977, 25-42). The goal is to reassure ethnic minorities and provide them with a stake in the society's politics. However, by elevating ethnocultural divisions to the main feature of a society's political life, consociational democracy raises a host of problems of its own.

Consociational democracy often sustains ethnic conflict at high levels. Since many government posts are allocated according to predetermined ethnic quotas, electoral competition takes place primarily within communities rather than on a broader national platform. Political leaders thus may be unable to compromise across group lines because they risk being outflanked by more radical challengers from within their own group who engage in 'ethnic outbidding' (Chandra 2005). The resulting political climate makes interethnic cooperation and compromise difficult, and it is 
likely to result in frequent decision-making deadlock (Rothchild and Roeder 2005). Moreover, there is no guarantee that the largest group(s) will abide by the constitution's consociational provisions (Horowitz 2014). Finally, consociational democracy often results in enforced within-group conformity and gives rise to the problem of 'minorities within minorities' that are left unprotected (Eisenberg and Spinner-Halev 2005).

Next, I briefly discuss recent international efforts to promote postwar majoritarian democracy (Afghanistan and Iraq) and consociational democracy (Bosnia-Herzegovina), in order to illustrate the problematic nature of such efforts. Western interventions in Afghanistan and Iraq were not primarily motivated by humanitarian concerns, although in both cases, the intervening states mentioned the regime's mistreatment of civilians as an additional justification for military action. Regardless of what motivated these interventions, the resulting collapse of existing authority structures at the beginning of the twenty-first century laid bare extreme ethnosectarian divisions. This makes the circumstances of Western efforts at democracy promotion in Afghanistan and Iraq similar to those that humanitarian interveners are likely to encounter after forcibly removing genocidal regimes.

\section{Majoritarian democracy: Afghanistan and Iraq}

In Afghanistan, the United States supervised the establishment of a majoritarian form of democracy after it forcibly toppled the Taliban regime in 2001. A broad-based constitutional Loya Jirga (Grand Council) of 500 Afghan delegates was convened in 2003 to deliberate on and approve a new constitution; however, the constitution's core provisions were drafted by a small commission appointed by Hamid Karzai, the US-backed interim president. Karzai and his ethnic Pashtun supporters wanted a majoritarian form of democracy with a strong, directly elected president (Rubin 2004, 6-13). Since Pashtuns make up at least $45 \%$ of the country's population, their expectation was that this would result in permanent Pashtun rule. The US special envoy, Zalmay Khalilzad, supported the idea of a directly elected, strong central executive, believing that this would facilitate postwar reconstruction and enable a rapid withdrawal of American troops (Thier 2010, 548-51).

The representatives of various Afghan minority groups, including Tajiks, Uzbeks, and Hazaras, favored consociational power sharing with a parliamentary form of government and a grand coalition-type central executive. Karzai and Khalilzad, however, pushed through their preferred solution: since the rules of procedure for the constitutional Loya Jirga were unclear, the constitution was considered ratified when a majority of 
delegates, mostly Pashtuns, stood up to show their support in January 2004 (Rubin 2004, 11-13; Thier 2010, 550-54). Pashtuns have dominated Afghan politics ever since, with little incentive to reach out to minority communities and provide public goods in an inclusive manner. Interethnic reconciliation has not been a priority, governmental discrimination against minority communities remains rampant, and Afghan authorities systematically violate the personal integrity rights of ethnic minority citizens (HRW 2015a, 46-51; DOS 2016, 47-51). Crucially, majoritarian democratic rule has done little to improve political stability and indeed may have harmed prospects for interethnic peace (Ottaway 2007; Nixon and Hartzell 2013).

The United States also helped establish a majoritarian form of democracy in Iraq after it invaded the country in 2003 and toppled Saddam Hussein's Baathist Sunni regime. Iraq's 2005 national electoral law, devised by the United States in cooperation with the United Nations secretariat, created a system of pure proportional representation with a single nationwide electoral district. Since Shias make up approximately $60 \%$ of Iraq's population, the electoral law practically ensured that the Shia community would dominate the democratically elected constitutional assembly; hence the constitution-making process as well and, by implication, Iraqi politics thereafter (Arato 2009, 207-9; Morrow 2010, 574-82).

In the absence of constitutionally mandated power sharing, subsequent national elections based on party-list proportional representation enabled Iraq's Shias to control most federal cabinet posts (ICG 2013). In 2010, under international pressure, Iraq's main political parties agreed that, henceforth, the country's president would be a Kurd, the prime minister a Shia, and the speaker of parliament a Sunni - however, this has not yielded substantial power sharing, as the positions of president and speaker of parliament are largely symbolic (Visser 2010). Iraq's democratically sanctioned Shia dominance has produced significant pressures on Iraq's Sunnis, including serious human rights violations involving 'mass detentions and trumped-up terrorism charges' (Arango 2015). This systematic discrimination, in turn, has led to growing Sunni support for radical Islamist opposition movements, including Al Qaeda and the so-called Islamic State, deeply destabilizing the country (Cordesman and Khazai 2014, 157-61).

\section{Consociational democracy: Bosnia-Herzegovina}

Consociational democracy, as noted, can yield more inclusive governance in ethnically divided societies. The postwar constitution for BosniaHerzegovina, imposed by the United States and its NATO allies as part of the Dayton Peace Agreement in 1995, is a textbook example of 
consociational democracy. ${ }^{8}$ The Dayton constitution sought to combine generous self-government rights for each of Bosnia's three 'constituent peoples' - Bosnian Muslims, Croats, and Serbs - with the preservation of a unitary state based on ethnic power sharing. The territory was divided into two autonomous entities (a majority-Serb Republika Srpska and a Muslim-Croat Federation), and most governmental functions were devolved to the entity level or further downward. Bosnia's head of state is a threeperson power-sharing body composed of a Bosnian Muslim, a Croat, and a Serb member. All important decisions concerning Bosnia as a whole have to be adopted by consensus, and each group has the ability to block legislation that it regards as contrary to its 'vital interests' (Belloni 2008, 44-50).

This intricate arrangement may have helped preserve political stability in the war's immediate aftermath. However, the institutional framework adopted at Dayton has elevated ethnocultural divisions into the defining characteristic of the country's political life. This has sustained ethnic conflict at high levels and, combined with a very cumbersome decisionmaking structure, has yielded frequent deadlock, hampering Bosnia's progress toward sustainable peace and European integration (Recchia 2007). The lack of meaningful checks on political power holders within each community has also resulted in persistent human rights violations (HRW 2015a, 110-13). Discrimination against members of other ethnic groups besides the country's three officially recognized ones is a particularly serious problem (Council of Europe 2014).

In short, if the objective is to safeguard ethnic minority interests after acute ethnic violence, then consociationalism appears preferable to majoritarian rule. Consociational democracy, however, favors competitive intergroup bargaining over deliberation and sustains communal conflict at high levels; thus, it may not be conducive to self-sustaining peace. Indeed, in Bosnia, more than two decades after the end of the war, the international community maintains an intrusive presence, which it deems necessary to prevent ethnic tensions from spiraling out of control (Merzdanovic 2017).

\section{Is democracy necessary for collective self-determination?}

It might be argued that humanitarian interveners nevertheless ought to promote electoral democracy in societies torn apart by genocide because

${ }^{8}$ The constitution was drafted entirely by U.S. and European lawyers and presented to the local parties as Annex 4 of the Peace Agreement on a 'take it or leave it' basis. According to James O'Brien $(2010,344)$, a former State Department lawyer who was involved in the drafting, the 'negotiations took place under a blackout, with neither informal public consultation during negotiations, nor formal... democratic approval thereafter.' 
democracy is the only means by which the goal of inclusive collective selfdetermination can be approximated, however imperfectly. Yet, democracy is not necessary to that end. In his extended essay The Law of Peoples (1999), Rawls made a powerful case that inclusive self-determination can be achieved through less than democratic political institutions, as long as they enable the representation of socially relevant groups.

\section{Rawls's decent hierarchical societies}

Rawls emphasizes that 'self-determination... is an important good for a people, and the foreign policy of liberal peoples should recognize that good' $(1999,85)$. He illustrates the features that would make a nondemocratic society self-determining (and thus deserving of full international recognition and respect) by describing a hypothetical 'decent hierarchical' people whose individual members are 'viewed in public life as members of different groups' (64). This allows for the possibility that these groups be of an ascriptive nature, ethnic or otherwise. ${ }^{9}$ What particular features, then, make a decent hierarchical society self-determining?

\section{Effective and legitimate laws that protect basic human rights}

A decent hierarchical society is endowed with an effective system of law that is not merely supported by force but instead enjoys widespread domestic legitimacy. The society's laws are both normatively legitimate, in the sense of being guided by a common good idea of justice that imposes 'bona fide moral duties and obligations on all persons within the people's territory,' and sociologically legitimate, in the sense that these persons sincerely believe that the laws are guided by a common good idea of justice (Rawls 1999, 65-66). For Rawls, the exercise of political power is legitimate only when it is in accordance with a basic structure that the society's members can accept as appropriate (Wenar 2006, 100).

While some ethnocultural groups may enjoy privileged status and access to political office (for instance, Islam might be 'the favored religion' in a society in which 'only Muslims can hold the upper positions of political authority' [Rawls 1999, 75]), minorities are made to feel included and more generally are not 'subjected to arbitrary discrimination, or treated as inferior' (Rawls 1999, 76). The requirement that minorities be included

${ }^{9}$ Rawls makes this possibility explicit a few pages later. Assuming, for example, that the society's majority religion was Islam, Rawls notes, a 'decent people is marked by its enlightened treatment of various non-Islamic religions and other minorities who have been living on its territory for generations' (1999, 76; emphasis added). 
and treated as members also involves protection of basic human rights, such as freedom from slavery and serfdom, formal equality under the law, and protection of the right to life - including 'security of ethnic groups from mass murder and genocide' (79; see also 65). Such basic human rights, as opposed to the full set of liberal rights that 'citizens have in a reasonable constitutional democra[cy]' (78), 'cannot be rejected as peculiarly liberal or special to the Western tradition' (65). Rawls insists that basic human rights are 'necessary conditions of any system of social cooperation' (68). Put differently, they are 'conditions of membership or inclusion': the protection of such basic rights indicates that people - including members of minority groups - are treated as members, which is necessary for joint collective self-determination (Cohen 2006, 233).

\section{Public consultation and deliberation}

Furthermore, the political institutions of a decent hierarchical society include a public consultation mechanism that 'provides an opportunity for different voices to be heard' and to be taken into account by policymakers (Rawls 1999, 72). Each of the society's principal groups is represented by a body in the consultation hierarchy. Special care has to be taken to ensure an adequate representation of traditionally disadvantaged groups, including women and ethnic minorities, which 'must be represented by a body that contains at least some of the group's own members' (77, 71-78 more generally). Although there is no democratic accountability, 'the rulers... must weigh the views and claims of each of the bodies consulted' and, if called upon, 'must explain and justify' their decisions in public (77). Each group has a right to 'express political dissent, and the government has an obligation to take a group's dissent seriously' and respond to it (72).

The goal of the public consultation structure is to promote deliberation on the public good and enable representative rule, albeit of a nondemocratic kind. Rawls notes that 'public deliberation is vital for a reasonable... regime, and specific arrangements need to be laid down to support and encourage it' $(1999,51)$. The need for political authorities to offer public justifications for their decisions does not automatically ensure publicregarding outcomes. However, it can be expected to have a prophylactic effect: 'by disciplining the kinds of reasons that may be offered in support of legislation, it should increase the likelihood that [public-regarding outcomes] will come about' (Sunstein 1993, 200).

Rawls's central point is that decent societies that respect the basic rights of people living on their territory and that are effectively self-determining should be free from external interference. Cosmopolitan liberals have taken issue with this argument: Rawls's decent societies, they point out, do not 
recognize all their members as fully equal and autonomous, thus falling lamentably short of liberal justice (see, e.g., Téson 1995; Tan 2006). Inspired by republican liberalism, however, Rawls in the Law of Peoples recognizes the moral significance of collective self-determination. Due respect for the project of collective self-determination 'requires that just [i.e., liberal-democratic] societies resist the impulse simply to universalize principles arrived at within the horizons of one people's institutions, history, and culture' (Macedo 2004, 1738).

For our purposes, the main insight from the foregoing discussion is that if the goal is to enable peaceful collective self-determination after mass atrocities, democracy promotion may be unnecessary. Instead, it may be sufficient for international interveners to facilitate the emergence of postwar political institutions that come as close as possible to the Rawlsian threshold of decency. It is worth stressing that Rawls's 'decent hierarchical society' is an ideal type: as Doyle (2006) shows, only a few societies in the contemporary world - notably, in the Persian Gulf and perhaps in Central Asia - approximate the ideal, but they do so imperfectly. That said, the Rawlsian ideal type of a just liberal democracy, too, is unlikely to be met fully in any really existing society. Hence, approximation of Rawls's ideal types is probably the best we can hope for.

\section{Toward hybrid governance}

The introduction of electoral democracy in societies recently torn apart by acute ethnic violence, as noted, is problematic because it is likely to result in either quasi-permanent domination of the political process by majority groups or deadlocked decision making marked by destabilizing forms of ethnic outbidding. International actors intent on countering these tendencies and ensuring that nominally democratic institutions do not plunge such societies back into violence may have to maintain a highly intrusive, trusteeship-like presence for a prolonged period - vetting candidates for democratic elections, setting the domestic political agenda, and even imposing particular policies (Tansey 2009).

I argue that to obviate the need for open-ended trusteeship, those who intervene to stop genocide and other forms of acute ethnic violence should not merely stop short of imposing Western-style democratic institutions based on competitive elections; instead, especially for societies that lack prior experience with liberal democratic rule, outside interveners should consider encouraging the adoption of postwar constitutions that limit democracy. Put differently, outsiders should seek to promote consociational, or power-sharing, political institutions; but to maximize the odds that these institutions will result in inclusive and effective governance, 
it may be worth tempering their democratic character, even when the largest ethnic groups demand full electoral democracy anticipating that they will benefit at the polls.

\section{Preventing 'disruption from below'}

Concretely, when it comes to reshaping the constitutional structure of deeply divided postbellum societies, international interveners should explore the possibility of promoting hybrid political institutions that combine some electoral accountability with reliance on unelected, customary authorities. Customary authorities enjoy significant social legitimacy in many agrarian and pastoral societies outside the Western world, whether in sub-Saharan Africa, Central Asia, or the South Pacific. Taking a society's prior history as a starting point, customary authorities could be integrated into the new postwar institutional architecture either nationally (at the central government level) or locally (at the district or municipality level). At the national level, customary authorities such as clan elders, religious leaders, and members of the traditional nobility could contribute to law making through a second, unelected legislative assembly along the lines of Britain's House of Lords. At the subnational level, assemblies of traditional leaders and consultation structures in which traditional chiefs or clan elders deliberate on public affairs with the public could become part of the recognized (and internationally supported) institutional architecture.

Relying on democratic elections as the only source of political authority in postgenocidal societies risks subjecting carefully balanced elite pacts to 'disruption from below,' since the mass public, still traumatized by the violence, is likely to be susceptible to extremist bids for support from nationalistic politicians (Chandra 2005; Sisk 2008). By contrast, including customary leaders who are not directly dependent on the support of democratic majorities into the state's mechanisms of political representation can facilitate pragmatic problem-solving and intergroup accommodation. As Menkhaus $(2000,197)$ notes with regard to the Horn of Africa region, 'elders and other traditional peacemakers are usually a force for reconciliation.' While the ability of such traditional leaders to resolve intergroup conflicts is 'constrained by the material interests of the communities to which they belong,' they usually do not need to rely on narrow ethnopopulism for their legitimacy and hence can take a broader view of the society's good (197).

More generally, the inclusion of customary authorities in the new postwar institutional architecture holds the promise of imbuing the entire state-building project with 'grounded legitimacy' (Boege, Brown, and 
Clements 2009; see also Chopra and Hohe 2004). Scholars have long emphasized that the prospects for lasting peace are greater when newly established postwar political institutions are in accord with custom and viewed as legitimate by the local population (see, e.g. Bhuta 2010; Wallis 2014). Hybrid governance that incorporates local customary practices may therefore contribute to the Rawlsian goal of 'stability for the right reasons,' whereby a society's members internalize the principles of justice embodied in the society's institutions and learn to cooperate peacefully in accordance with those principles (Rawls 1999, 44-45).

To the extent that preexisting customary governance structures are fundamentally abusive and violate basic human rights, they are in need of reform. But frequently, existing customary governance structures with roots in the precolonial period reflect indigenous traditions of public consultation and inclusive rule; thus, they may offer a platform for a diversity of voices and opinions to be expressed and be quite responsive to people's needs. In short, they can be representative and help protect basic human rights even as they fall short of formal democracy (Belloni 2012). One recent study even suggests that hybrid governance increases the likelihood that public funds will benefit the broader population in fragile states, because traditional chiefs who are deeply socially embedded in their communities are well placed to facilitate the implementation of local development projects (Baldwin 2016).

\section{In defense of partial electoral accountability}

In an important study, Barnett (2006) touts the merits of unelected assemblies of traditional leaders at the postwar reconstruction stage, as instruments for promoting the discovery of common interests among former warring parties. For Barnett, such unelected assemblies should be viewed as relatively short-term transitional arrangements that may remain in place for several months 'until elections are appropriate' and, during this period, 'can perform the function of representation' (2006, 102). My argument differs from Barnett's in two ways: first, I want to suggest that unelected assemblies should coexist with, rather than replace, democratic bodies; second, I argue that such unelected assemblies might be useful to consolidate state building in the medium to long term, over a period of several years. My argument is thus closer to Chopra and Hohe's claim $(2004,301)$ that when indigenous structures are already functioning and fairly inclusive, or can be revived and made more representative with outside help, there may be no need for deeper social engineering in the short term, but 'equally, it may not make sense to seek to transform the existing structures in the long term, because of their acceptability and usefulness as the foundation for state-building efforts.' 
In principle, following the Rawlsian framework, to the extent that a representative political process could be sustained in the absence of any electoral accountability, we should tolerate it and respect it. Rawls explains that his 'remarks about a decent hierarchical society are conceptual,' and 'should [such a society] exist... it should be tolerated politically' (1999, 75 n. 16; see also Tan 2006, 77-80). In practice, however, it is unclear that a system that relies exclusively on indigenous consultation structures and unelected assemblies would be capable of providing adequate safeguards against a progressive degeneration into tyranny. Absent continued international interference, a powerful, charismatic ruler might be able to co-opt his or her allies into the unelected assembly, thus reducing its representative character and gradually eroding any checks on executive power (see also Christiano 2011, 156-59). Hence my argument that unelected assemblies should be combined with elements of democratic (electoral) accountability. ${ }^{10}$

The resulting arrangements would resemble a classical 'mixed constitution' incorporating elements of democracy and traditional aristocracy, as discussed and praised by thinkers from Plato and Polybius to the republican liberals of the Federalist Papers. For ancient and medieval European thinkers, in particular, the main purpose of the mixed constitution was to foster accountable government while moderating the impact of popular rule by ensuring that the nobles and the people would check and balance each other (Blythe 1992, Ch. 2). Similarly, today, in divided societies recovering from ethnic violence, mixed or hybrid political institutions could ensure representative government while providing a bulwark against nationalistic disruption from below.

Once a postwar society becomes collectively self-determining, in the sense that political decisions reflect the views and interests of all established communities and basic human rights are generally respected, the question of whether that society should advance on the path toward liberalism and democracy or maintain a decent but only partially democratic hybrid political structure should be answered by none but the affected population itself, relying on its own mechanisms of political representation. ${ }^{11}$ As Rawls $(1999,61)$ reminds us, 'it is surly, ceteris paribus, a good for individuals and associations to be attached to their particular culture' and to live under

${ }^{10}$ It would also be hard to argue that international actors, on their own authority, should resist democracy entirely when it is demanded by important domestic groups, even though these groups may demand it for self-interested reasons. For a similar argument, see Doyle $(2015,165-71)$.

${ }^{11}$ Hence my proposal differs from arguments in favor of delayed democratization, or 'institutionalization before democratization' (see, e.g., Paris 2004), which still view full electoral democracy as the only possible long-term solution. 
political institutions that as much as possible reflect and express that culture. 'If a liberal constitutional democracy is, in fact, superior,' he notes, then liberals should trust that a decent society will over time 'take steps toward becoming more liberal on its own' (62).

\section{Hybrid governance in practice}

To illustrate the possible benefits of hybrid governance for deeply divided postbellum societies, I briefly discuss two real-world examples, Somaliland and Bougainville. These examples are imperfect in several respects. Although both are largely self-governing territories marked by significant ethnocultural diversity and a history of violent communal conflict, neither is yet an internationally recognized sovereign state. Moreover, in Somaliland, international actors have played only a very limited role. Finally, respect for basic human rights, an important characteristic of decent societies, is far from universally achieved in either territory.

Nevertheless, these examples are helpful insofar as they indicate that customary bodies may be fruitfully combined with democratically elected ones to promote inclusive, socially legitimate governance and durable peace. I thus emphasize the 'inclusive governance' element of the Rawlsian conception of decency above other components. Somaliland and Bougainville are free from systematic violence against or enslavement of political opponents and ethnocultural minorities. The main ethnic groups, clans, and tribes are included in the political process and help shape collective decisions, even though some groups enjoy privileged status. As to shortcomings in human rights protection (discrimination against women, for instance, remains pervasive in both societies), these phenomena, while serious, should be kept in perspective: in divided societies recovering from communal violence, human rights violations are often widespread regardless of the political system. International actors should do more to promote respect for basic human rights in such societies through education and by offering various incentives, but introducing full electoral democracy, as noted, will not necessarily make the task easier and could make it more difficult.

\section{Somaliland}

The 'Republic of Somaliland' has been a de facto independent state since it broke away from Somalia in 1991. That year, a rebel movement drawing support from Somaliland's main clan, the Isaaq, unilaterally declared the territory's independence. Most other local clans and subclans supported the declaration, but some did not, resulting in a turbulent transition marked by significant communal violence. In 1992, Somaliland's clan elders negotiated a cease-fire, and over the next several months they consolidated the peace, 
initiating a bottom-up state-building project. They created a national legislative council of elders (the Guurti) and established an inclusive interim government led by Mohammed Ibrahim Egal, an experienced Isaaq politician who had served as Somalia's prime minister in the 1960s. These initial stages of postwar governance were marked by a representative, if entirely undemocratic, political process: for several years, the government was essentially a power-sharing coalition of Somaliland's main clans and subclans. As the security situation improved by the mid- to late 1990s, the power-sharing government was able to restore essential services, set up state ministries, reintegrate displaced populations, and establish a rudimentary legal system and police force (Richards 2014, 101-9).

This carefully calibrated system of clan-based governance, however, 'remained politically vulnerable to shifts in power relationships between the clans' (Bradbury, Abokor, and Yusuf 2003, 461; see also Renders and Terlinden 2010, 729-30). In 1997, to address this challenge, Somaliland's clan leaders began drafting a new constitution that introduced elements of democratic representation. President Egal and several clan elders also believed that a partial democratization of the system would help gain international recognition for Somaliland as an independent state (Richards 2014, 116-17). At the same time, many locals reportedly felt that peace and stability were more important than democracy and could be sustained without it, and indeed they worried about the implications of moving toward a more competitive system based on majority rule. Somaliland's permanent constitution, drafted by clan leaders and adopted in a popular referendum in 2001, sought to strike a balance between these concerns (Bradbury, Abokor, and Yusuf 2003, 464; see also Richards 2014, 149).

The 2001 constitution, which has been in force ever since, established a new hybrid political system that combines elements of electoral democracy with traditional clan-based governance. The president of Somaliland and members of the lower legislative chamber, the house of representatives, are democratically elected by universal suffrage; meanwhile, the upper house, or house of elders (known as the Guurti), is a nonelected assembly whose membership is drawn from the clan elders. The upper house reviews legislation adopted by the house of representatives, but it can return a bill only once - meaning that if the house of representatives votes to push the bill back unchanged, it is considered adopted. (If the upper house rejects a bill by a two-thirds majority, the lower house needs to approve it by the same majority to overcome the elders' veto ${ }^{12}$ ). In this way, the house of elders functions as a

12 Constitution of the Republic of Somaliland, Articles 54, 61, 77. Accessed October 23, 2017, http://www.somalilandlaw.com/Somaliland_Constitution/body_somaliland_constitution. 
check on majority rule and promotes consensus-oriented governance, while at the same time the rules of procedure limit the risk of decision-making deadlock (see also Hesse 2010).

The new hybrid political structure has prevented any single group from dominating the political process and, according to some observers, 'guarded against the re-emergence of authoritarian rule' during the postwar transition (Bradbury, Abokor, and Yusuf 2003, 462). Clan-based governance in the region has traditionally been deliberative, with decisions reached by consensus (Menkhaus 2000). This tradition has by and large been maintained within the new statewide Guurti, providing a useful counterweight to the more competitive and sometimes confrontational politics within the democratically elected lower house (Richards 2014, 64-73, 138-50; see also Hesse 2010, 71).

Somaliland's experience with hybrid governance, largely unassisted by the outside world, has not been unproblematic. Given Somaliland's tradition of consensus-oriented governance and the Guurti's consociational structure, a parliamentary form of government might have been more appropriate than the presidential system that was chosen. President Egal, who remained in power until his death in 2002, and subsequent presidents have used their paramount position and the lack of clear guidelines for appointment to the national Guurti to place many of their loyalists in the upper legislative chamber. This has gradually reduced the Guurti's representative character and its ability to act as a check on presidential power (Renders and Terlinden 2010, 733-35; Hoehne 2013, 203-7). Arguably, greater international involvement in Somaliland's state-building project through financial and technical assistance, especially if tied to the prospect of international recognition, could have resulted in (1) a parliamentary form of government more appropriate for a consociational, hybrid political system; (2) a clearer set of criteria for appointment to the national Guurti, limiting the president's prerogative in this field; and (3) better protection of basic human rights and higher levels of commitment to gender equality. ${ }^{13}$

Nevertheless, measured by the standards of other conflict-torn societies in sub-Saharan Africa, Somaliland has enjoyed impressive successes. It maintains a high level of public security, has built up a modest but functioning state, and, according to the Minority Rights Group, an international nongovernmental organization, 'awareness and action for minority rights have advanced further and faster in Somaliland than in

htm\#_ednref134. See also "Somaliland Parliament”. Accessed October 23, 2017, http://www. somalilandlaw.com/body_somaliland_parliament.html.

13 The human rights situation in Somaliland, although better than elsewhere in the Horn of Africa, remains precarious, and the participation of women in politics is very low (Hesse 2010, 75). 
south-central Somalia' and elsewhere in the region (Hill 2010). Several studies suggest that Somaliland's hybrid political system has imbued the state-building project with social legitimacy and has helped ensure that the main ethnocultural groups feel included and perceive a stake in the political process (Bradbury, Abokor, and Yusuf 2003, 462-65; Hesse 2010, 81-82; Richards 2014, Ch. 5).

\section{Bougainville}

Bougainville is a largely self-governing island territory in the South Pacific. To date, it remains part of the state of Papua New Guinea (PNG), although it may become a sovereign state after an independence referendum scheduled for June 2019 (RNZ 2016). For almost a decade between 1989 and 1998, Bougainville was the theater of a bloody civil war that began as a conflict over mining revenue but morphed into a communal conflict between pro- and anti-independence groups. The civil war in its later stages involved what one observer (Boege 2010, 338) calls a 'complex mixture... of localized sub- or mini-wars between traditional societal entities (such as clans or villages).' Consequently, after a cease-fire was achieved in early 1998, building peace required bringing a deeply fractured society back together. Peace talks mediated by New Zealand yielded a comprehensive peace agreement in 2001 that led to the establishment of a power-sharing interim government. The interim government then appointed a broadbased constitutional commission tasked with drafting a new constitution for the autonomous territory. After a 2-year deliberation process that included multiple rounds of consultation with local groups, Bougainville's new constitution was adopted in November 2004 (Regan 2013, 425-26; Wallis 2014, 200-25).

The new constitution, currently in force, established a hybrid political structure that combines liberal democracy for the Autonomous Bougainville Government (ABG) with customary governance at the local level. The ABG's primary legislative organ is a democratically elected house of representatives. Its executive branch consists of an 'executive council' headed by the territory's directly elected president, who then appoints other members. There are specific provisions for the representation of women and regional minorities in both the ABG's legislative and executive branches (Regan 2013, 429). The draft constitution, responding to civil society demands that emerged during the consultations, also foresaw an unelected upper house composed of customary representatives such as chiefs and other traditional leaders - similar to Somaliland's Guurti. However, as a result of concerns expressed by the PNG government, the upper house was ultimately downgraded to an 'advisory body,' tasked with advising the executive branch on constitutional 
amendments and other matters referred to it (Wallis 2014, 267). The advisory body has yet to be established: the constitution simply notes that this will happen once the ABG's efforts 'to achieve fiscal self-reliance have progressed to the point where the establishment... is sustainable' (Bougainville Autonomous Constitution (BC) 2004, art. 52.2).

At the local level, meanwhile, traditional authorities have to a considerable degree been integrated into Bougainville's new constitutional architecture from the beginning. Wallis $(2014,268)$ reports that during the constitutional consultations, Bougainvilleans expressed their 'desire for chiefs and local sociopolitical institutions to be recognized as the basis of formal government at the village level. People expressed the perception that liberal institutions were "remote" and hard to "understand or obey." Boege $(2010,346)$ similarly notes that for Bougainville's majority rural population, the legitimacy of customary governance mechanisms 'is often much higher than that of the modern state.' The ABG's weak capacity provided additional incentives to revive customary local authority structures in order to facilitate the maintenance of public order and the provision of basic services (Regan 2013, 430).

Bougainville's constitution notes that the ABG 'shall devolve governmental functions and powers to... customary communities' (BC 2004, art. 14.3). The statutes recognize two tiers of customary local government: first, there are about 600 village assemblies, led by a traditional chief; second, the representatives of several village assemblies together form a district-level council of elders (COE), of which there are currently about 90 (Wallis 2014, 268-70).

The village assemblies approximate a Rawlsian decent consultation structure: traditional village chiefs in charge of local government and dispute resolution consult with the village population through regular public meetings, which are held about once a week and to which all village residents are invited. The meetings usually consist of daylong deliberations, during which the chief leads a discussion on village governance and other local issues (Sasa 2013, 29-31, 52-59; Wallis 2014, 269-73).

Each village assembly, typically through a consensual deliberative process, also appoints its own representative (not necessarily the village chief) to a district-level COE. The COEs are vested with legislative, executive, and judicial powers pertaining to the maintenance of law and order in their areas. Problems are usually solved by relying on custom, and only if this is not possible, statutory law may be invoked (Boege 2010; Wallis 2014, 270). People can hold local COE members to account through village assembly meetings, which they can request for that specific purpose; alternatively, people can ask their clan chief to take up their grievances with the local COE member (Sasa 2013, 63-64). 
Although Bougainville approximates Rawlsian decency in terms of inclusive governance, significant challenges persist for public policy. Bougainville remains extremely poor in socioeconomic terms, even compared with other developing countries in the region - in spite of the fact that access to basic services has been improving (Chand 2013, 10-15). As in PNG more generally and in many traditional Melanesian societies, domestic violence against women remains a serious problem, which customary authorities have been unwilling to address decisively (HRW 2015b). But here, too, things may be starting to change: the United Nations Peacebuilding Support Office recently launched a series of initiatives to raise awareness about gender violence across Bougainville and increase women's participation in village assemblies, with encouraging initial results (PBSO 2015). Reportedly, in contrast to only a few years ago, it is now quite common for women to outnumber men in village assembly meetings (Palipal 2015). This suggests that women may, in the future, exert greater influence on local policymaking.

In spite of the aforementioned challenges, there are strong indications that Bougainville's hybrid institutions have facilitated public goods provision and increased the perceived legitimacy of the territory's political system among local inhabitants (Wallis 2014, 273). Some evidence even suggests that public goods are provided at a higher level in Bougainville than in the rest of PNG, possibly facilitated by traditional authorities who are deeply embedded in and responsive to local communities (Wallis 2014, 281). People's participation in customary local governance also appears to have had a catalytic effect on societal reconciliation (Boege 2010, 338). Today, ethnocultural minorities are generally well integrated across the territory, and the significant Polynesian minority does not experience discrimination (Minority Right Group 2017). In short, Bougainville's hybrid institutions, with external support, have helped bring a war-torn society back together, fostering inclusive collective self-determination.

\section{Conclusion}

This article has challenged the predominant view among jus post bellum theorists that when liberal countries intervene to stop genocide, they subsequently ought to promote democratic political institutions based on competitive elections. Instead, I have argued, in the aftermath of acute ethnic violence, international interveners should consider promoting hybrid institutions that circumscribe democracy by combining popularly elected bodies with customary authority structures. Especially when a society lacks prior experience with liberal democracy, hybrid governance may be better placed than full popular rule to ensure an inclusive, socially legitimate 
political system and thus to facilitate peaceful self-determination. The article's focus has been on the aftermath of humanitarian interventions to stop genocide, mirroring the focus of jus post bellum theorists; however, hybrid institutions such as those discussed in this article may offer an appealing solution to the governance problems facing divided societies recovering from communal violence more generally.

Hybrid institutions are no panacea. Customary authorities are often prone to corruption, especially when they enjoy lifelong tenure. Hybrid governance may also give rise to systems of patronage, as when elected presidents maneuver their own loyalists into powerful posts on customary decision-making bodies (Belloni 2012; Hoehne 2013). However, these potential flaws should be kept in perspective. Patronage and corruption are often endemic in weak states recovering from civil conflict, even when the political system is nominally liberal and democratic. Indeed, democratic competition in war-torn societies may produce greater incentives to engage in patronage and corruption, as spoilers within each community - those engaging in ethnic outbidding - have to be bought off to keep powerful centrifugal forces at bay (Cheng and Zaum 2011). Hybrid institutions, by contrast, can provide valuable customary checks on rent seeking and corruption (Boege, Brown, and Clements 2009).

Scholars within the critical theory tradition emphasize that 'hybridity is not a condition that can be crafted in a laboratory and rolled out in neat factory packaging' (Mac Ginty and Richmond 2016, 220). Postwar institutions, hybrid or not, should indeed never simply be imposed from the outside following a cookie cutter approach. Nevertheless, we ought to take seriously the possibility that international actors can play a useful role in fostering the emergence and influencing the shape of hybrid postwar political institutions, which in many cases could be grafted onto preexisting customary structures. In particular, international actors may be able to facilitate the emergence of a representative political process that offers adequate safeguards for ethnocultural minorities and protects basic human rights, thus approximating the Rawlsian ideal type of decent governance. The approach outlined in this article therefore leaves considerable scope for international interference aimed at setting war-torn societies on the path toward inclusive collective selfdetermination. Inclusive self-determination, however, does not require and is not always best achieved by promoting Western-style electoral democracy.

\section{Acknowledgments}

The author would like to thank workshop participants at Sciences Po Paris, the Free University of Berlin, the European Academy of Bolzano, and the Global International Studies Conference in Frankfurt for helpful comments 
on previous versions of this paper. Special thanks go to Duncan Bell, Ariel Colonomos, Michael Doyle, Marine Guillaume, Daniel Jacob, Pablo Kalmanovitz, Bernd Ladwig, Steve Krasner, Costantino Pischedda, and Lea Ypi. Open access publication was made possible by a Career Integration Grant from the European Commission.

\section{References}

Arango, Tim. 2015. "Iraq's Sunnis Are Pushed Further to the Margins.” New York Times, May 20: A1.

Arato, Andrew. 2009. Constitution Making Under Occupation: The Politics of Imposed Revolution in Iraq. New York: Columbia University Press.

Baldwin, Kate. 2016. The Paradox of Traditional Chiefs in Democratic Africa. Cambridge: Cambridge University Press.

Barnett, Michael. 2006. "Building a Republican Peace: Stabilizing States After War." International Security 30(4):87-112.

Bass, Gary. 2004. “Jus Post Bellum.” Philosophy and Public Affairs 32(4):384-412.

Belloni, Roberto. 2008. State Building and International Intervention in Bosnia. London: Routledge.

Belloni, Roberto. 2012. "Hybrid Peace Governance: Its Emergence and Significance." Global Governance 18(1):21-38.

Bhuta, Nehal. 2010. "New Modes and Orders: The Difficulties of a Jus Post Bellum of Constitutional Transformation." University of Toronto Law Journal 60(3): 799-854.

Blythe, James M. 1992. Ideal Government and the Mixed Constitution in the Middle Ages. Princeton, NJ: Princeton University Press.

Boege, Volker. 2010. "How to Maintain Peace and Security in a Post-conflict Hybrid Political Order-The Case of Bougainville." Journal of International Peacekeeping 14(3):330-52.

Boege, Volker, M. Anne Brown, and Kevin P. Clements. 2009. "Hybrid Political Orders, Not Fragile States." Peace Review 21(1):13-21.

Bougainville Autonomous Constitution (BC). 2004. Accessed October 23, 2017. http://www. paclii.org/pg/constitution-bougainville-2004.html.

Bradbury, Mark, Adan Yusuf Abokor, and Haroon Ahmed Yusuf. 2003. "Somaliland: Choosing Politics over Violence.” Review of African Political Economy 30(97):455-78.

Buchanan, Allen. 2003. Justice, Legitimacy, and Self-Determination: Moral Foundations for International Law. New York: Oxford University Press.

Chand, Satish. 2013. "Building Peace in Bougainville: Measuring Recovery Post-Conflict." SSGM Discussion Paper 2013/5, Australian National University. Accessed October 23, 2017. https://openresearch-repository.anu.edu.au/handle/1885/11403/.

Chandra, Kanchan. 2005. "Ethnic Parties and Democratic Stability." Perspectives on Politics $3(2): 235-52$.

Cheng, Christine, and Dominik Zaum. 2011. "Selling the Peace? Corruption and Post-conflict Peacebuilding." In Corruption and Post-Conflict Peacebuilding, edited by Christine Cheng and Dominik Zaum, 1-25. Abingdon: Routledge.

Chesterman, Simon. 2004. You, the People: The United Nations, Transitional Administration, and State Building. New York: Oxford University Press.

Chopra, Jarat, and Tanja Hohe. 2004. "Participatory Intervention." Global Governance 10(3):289-305. 
Christiano, Thomas. 2011. "An Instrumental Argument for a Human Right to Democracy." Philosophy and Public Affairs 39(2):142-76.

Cohen, Joshua. 2006. "Is There a Human Right to Democracy?" In The Egalitarian Conscience: Essays in Honour of G. A. Cohen, edited by Christine Sypnowich, 226-48. Oxford: Oxford University Press.

Cordesman, Anthony, and Sam Khazai. 2014. Iraq in Crisis. Lanham, MD: Rowman \& Littlefield.

Council of Europe. 2014. "Third Opinion on Bosnia and Herzegovina Adopted on 7 March 2013." Advisory Committee on the Framework Convention for the Protection of National Minorities, Doc. ACFC/OP/III(2013)003. Accessed October 23, 2017. https:// rm.coe.int/168008c667.

Davenport, Christian. 2007. "State Repression and Political Order." Annual Review of Political Science 10:1-23.

Davenport, Christian, and David Armstrong. 2004. "Democracy and the Violation of Human Rights: A Statistical Analysis from 1976 to 1996.” American Journal of Political Science 48(3):538-54.

de Waal, Alex, Jens Meierhenrich, and Bridget Conley-Zilkic. 2012. "How Mass Atrocities End: An Evidence-Based Counter-Narrative." Fletcher Forum of World Affairs 31(1):15-31.

DOS (Department of State). 2016. "Afghanistan Human Rights Report.” Accessed October 23, 2017. https://www.state.gov/documents/organization/265742.pdf.

Doyle, Michael. 2006. "One World, Many Peoples: International Justice in John Rawls's The Law of Peoples." Perspectives on Politics 4(1):109-20.

Doyle, Michael. 2015. The Question of Intervention. New Haven, CT: Yale University Press.

Eisenberg, Avigail, and Jeff Spinner-Halev. 2005. Minorities Within Minorities: Equality, Rights and Diversity. Cambridge: Cambridge University Press.

Fixdal, Mona. 2012. Just Peace: How Wars Should End. London: Palgrave Macmillan.

French, Stanley, and Andres Gutman. 1974. "The Principle of National Self-Determination." In Philosophy, Morality, and Public Affairs, edited by Virginia Held, Sidney Morgenbesser, and Thomas Nagel, 138-53. New York: Oxford University Press.

Hartzell, Caroline, and Matthew Hoddie. 2003. "Institutionalizing Peace: Power Sharing and Post-Civil War Conflict Management." American Journal of Political Science 47(2): 318-332.

Hesse, Brian J. 2010. "Lessons in Successful Somali Governance.” Journal of Contemporary African Studies 28(1):71-83.

Hill, Martin. 2010. No Redress: Somalia's Forgotten Minorities. London: Minority Rights Group International. Accessed October 23, 2017. http://minorityrights.org/publications/ no-redress-somalias-forgotten-minorities-november-2010.

Hinnebusch, Raymond. 2014. "The Arab Uprising and the Stalled Transition Process." In Mediterranean Yearbook, 17-22. Barcelona: European Institute of the Mediterranean. Accessed November 30, 2017. http://www.iemed.org/publicacions-en.

Hoehne, Markus Virgil. 2013. "Limits of Hybrid Political Orders: The Case of Somaliland." Journal of Eastern African Studies 7(2):199-217.

Horowitz, Donald L. 2014. "Ethnic Power Sharing: Three Big Problems.” Journal of Democracy 25(2):5-20.

HRW (Human Rights Watch). 2015a. "World Report 2015-Events of 2014.” Accessed October 23, 2017. http://www.hrw.org/sites/default/files/wr2015_web.pdf.

HRW (Human Rights Watch). 2015b. "Bashed Up: Family Violence in Papua New Guinea.” Accessed October 23, 2017. https://www.hrw.org/sites/default/files/report_pdf/png1115_ 4up.pdf. 
ICG (International Crisis Group). 2013. "Make or Break: Iraq's Sunnis and the State.” Middle East Report 144. Accessed October 23, 2017. https://www.crisisgroup.org/middle-eastnorth-africa/gulf-and-arabian-peninsula/iraq/make-or-break-iraq-s-sunnis-and-state/.

Jacob, Daniel. 2014. Justice and Foreign Rule: On International Transitional Administration. London: Palgrave Macmillan.

Joshi, Madhav, and T. David Mason. 2011. "Civil War Settlements, Size of Governing Coalition, and Durability of Peace in Post-Civil War States." International Interactions 37(4): 388-413.

Kumar, Radha. 1997. “The Troubled History of Partition.” Foreign Affairs 76(1):22-34.

Lazar, Seth. 2014. "Skepticism about Jus Post Bellum." In Morality, Jus Post Bellum, and International Law, edited by Larry May and Andrew Forcehimes, 204-22. Cambridge: Cambridge University Press.

Lijphart, Arend. 1977. Democracy in Plural Societies. New Haven, CT: Yale University Press.

Lijphart, Arend. 1999. Patterns of Democracy: Government Forms and Performance in ThirtySix Countries. New Haven, CT: Yale University Press.

Macedo, Stephen. 2004. "What Self-Governing Peoples Owe to One Another: Universalism, Diversity, and the Law of Peoples." Fordham Law Review 72(5):1721-38.

Mac Ginty, Roger, and Oliver Richmond. 2016. "The Fallacy of Constructing Hybrid Political Orders: A Reappraisal of the Hybrid Turn in Peacebuilding." International Peacekeeping 23(2):219-39.

Mann, Michael. 2005. The Dark Side of Democracy: Explaining Ethnic Cleansing. New York: Cambridge University Press.

McMahan, Jeff. 1996. "Intervention and Collective Self-Determination." Ethics and International Affairs 10(1):1-24.

Melandri, Manuela. 2011. "The State, Human Rights and the Ethics of War Termination: What Should a Just Peace Look Like?” Journal of Global Ethics 7(3):241-49.

Menkhaus, Kenneth. 2000. "Traditional Conflict Management in Contemporary Somalia." In Traditional Cures for Modern Conflicts, edited by I. William Zartman, 183-99. Boulder, CO: Lynne Rienner.

Merzdanovic, Adis. 2017. “'Imposed Consociationalism': External Intervention and Power Sharing in Bosnia and Herzegovina." Peacebuilding 5(1):22-35.

Minority Right Group. 2017. Papua New Guinea: Bongainvilleans. Accessed October 23, 2017. http://minorityrights.org/minorities/bougainvilleans/.

Morrow, Jonathan. 2010. "Deconstituting Mesopotamia: Cutting a Deal on the Regionalization of Iraq." In Framing the State in Times of Transition: Case Studies in Constitution Making, edited by Laurel E. Miller, 563-600. Washington, DC: USIP Press.

Nixon, Hamish, and Caroline Hartzell. 2013. "Beyond Power-Sharing: Institution Options for an Afghan Peace Process." In Getting it Right in Afghanistan, edited by Scott Smith, Moeed Yusuf, and Colin Cookman. Washington, DC: USIP Press.

O'Brien, James C. 2010. “The Dayton Constitution of Bosnia and Herzegovina.” In Framing the State in Times of Transition, edited by Laurel Miller, 332-49. Washington, DC: USIP Press.

Orend, Brian. 2002. "Justice After War." Ethics and International Affairs 16(1):43-58.

Orend, Brian. 2006. The Morality of War. Peterborough, ON: Broadview.

Ottaway, Marina. 2007. "Is Democracy the Answer?" In Leashing the Dogs of War: Conflict Management in a Divided World, edited by Chester A. Crocker, Fen Osler Hampson, and Pamela Aall, 603-18. Washington, DC: USIP Press.

Palipal, Ishmael. 2015. "Apiatei Women Empowered by Community Decision Making." Bougainville 24.com, July 30.

Paris, Roland. 2004. At War's End: Building Peace after Civil Conflict. Cambridge: Cambridge University Press. 
Patten, Alan. 2016. "Self-Determination for National Minorities." In The Theory of SelfDetermination, edited by Fernando Téson, 120-44. Cambridge: Cambridge University Press.

Pattison, James. 2015. "Jus Post Bellum and the Responsibility to Rebuild." British Journal of Political Science 45(3):635-61.

PBSO (Peacebuilding Support Office, United Nations). 2015. "Community-Level Peacebuilding Activities Addressing Conflict Related Trauma and Gender Based Violence.” Accessed October 23, 2017. http://mptf.undp.org/document/download/14059.

Philpott, Daniel. 1995. “In Defense of Self-Determination.” Ethics 105(2):352-85.

Rawls, John. 1999. The Law of Peoples. Cambridge, MA: Harvard University Press.

Recchia, Stefano. 2007. "Beyond International Trusteeship: EU Peacebuilding in Bosnia and Herzegovina." Occasional Paper 66, European Union Institute for Security Studies. Accessed October 23, 2017. https://www.iss.europa.eu/sites/default/files/EUISSFiles/occ66.pdf.

Recchia, Stefano. 2009. "Just and Unjust Postwar Reconstruction: How Much External Interference Can Be Justified?" Ethics and International Affairs 23(2):165-87.

Regan, Anthony J. 2013. "Autonomy and Conflict Resolution in Bougainville, Papua New Guinea.” In Practising Self-Government: A Comparative Study of Autonomous Regions, edited by Yash Ghai and Sophia Woodman, 412-48. Cambridge: Cambridge University Press.

Renders, Marleen, and Ulf Terlinden. 2010. "Negotiating Statehood in a Hybrid Political Order: The Case of Somaliland.” Development and Change 41(4):723-46.

Richards, Rebecca. 2014. Understanding Statebuilding: Traditional Governance and the Modern State in Somaliland. Farnham: Ashgate.

RNZ (Radio New Zealand). 2016. "Ball Rolling on Bougainville Referendum.” May 23. Accessed October 23, 2017. http://www.radionz.co.nz/international/pacific-news/ 304534/ball-rolling-on-bougainville-referendum/.

Rothchild, Donald, and Philip G. Roeder. 2005. "Power Sharing as an Impediment to Peace and Democracy." In Sustainable Peace: Power and Democracy after Civil Wars, edited by Philip G. Roeder and Donald Rothchild, 29-50. Ithaca, NY: Cornell University Press.

Rubin, Barnett. 2004. "Crafting a Constitution for Afghanistan." Journal of Democracy 15(3):5-19.

Sasa, Carol Lida. 2013. "Local Government Accountability in Bougainville." MPhil thesis, Massey University, New Zealand. Accessed October 23, 2017. https://mro.massey.ac.nz/ bitstream/handle/10179/4759/02_whole.pdf.

Sisk, Timothy. 2008. "Peacebuilding as Democratization." In From War to Democracy: Dilemmas of Peacebuilding, edited by Anna K. Jarstad and T. Sisk, 239-59. Cambridge: Cambridge University Press.

Snyder, Jack. 2002. From Voting to Violence: Democratization and Nationalist Conflict. New York: W. W. Norton.

Stahn, Carsten. 2006. “'Jus ad bellum', 'jus in bello'... 'jus post bellum'?-Rethinking the Conception of the Law of Armed Force." European Journal of International Law 17(5):921-43.

Sunstein, Cass. 1993. “The Enduring Legacy of Republicanism.” In A New Constitutionalism: Designing Political Institutions for a Good Society, edited by Stephen L. Elkin and Karol Edward Soltan, 174-205. Chicago: University of Chicago Press.

Tan, Kok-Chor. 2006. “The Problem of Decent Peoples.” In Rawls's Law of Peoples: A Realistic Utopia?, edited by Rex Martin and David A. Reidy, 76-94. New York: Blackwell.

Tansey, Oisin. 2009. Regime-Building: Democratization and International Administration. New York: Oxford University Press.

Téson, Fernando. 1995. “The Rawlsian Theory of International Law.” Ethics and International Affairs 9(1):79-99. 
Téson, Fernando. 2005. "Ending Tyranny in Iraq.” Ethics and International Affairs 19(2):1-20. Thier, Alexander J. 2010. "Big Tent, Small Tent: The Making of a Constitution in Afghanistan." In Framing the State in Times of Transition: Case Studies in Constitution Making, edited by Laurel E. Miller, 535-62. Washington, DC: USIP Press.

United Nations. 2005. "Report of the International Commission of Inquiry on Darfur.” Accessed October 23, 2017. http://www.un.org/news/dh/sudan/com_inq_darfur.pdf.

Visser, Reidar. 2010. "Baghdad's Phantom Power-Sharing Plan.” Foreign Affairs snapshot, December 3.

Wallis, Joanne. 2014. Constitution Making during State Building. Cambridge: Cambridge University Press.

Walzer, Michael. 1977. Just and Unjust Wars: A Moral Argument with Historical Illustrations. New York: Basic Books.

Walzer, Michael. 2012. "The Aftermath of War: Reflections on Jus Post Bellum.” In Ethics beyond War's End, edited by Eric Patterson, 35-46. Washington, DC: Georgetown University Press.

Weinstein, Jeremy. 2005. "Autonomous Recovery and International Intervention in Comparative Perspective." Working Paper 57, Center for Global Development. Accessed October 23, 2017. http://www.cgdev.org/files/2731_file_WP57.pdf.

Wenar, Leif. 2006. "Why Rawls Is Not a Cosmopolitan Egalitarian.” In Rawls's Law of Peoples: A Realistic Utopia?, edited by Rex Martin and David A. Reidy, 95-113. New York: Blackwell.

Western, Jon. 2012. “The Origins of Liberal Statebuilding.” In The International Community and Statebuilding: Getting Its Act Together?, edited by Patrice McMahon and Jon Western, 25-40. New York: Routledge. 